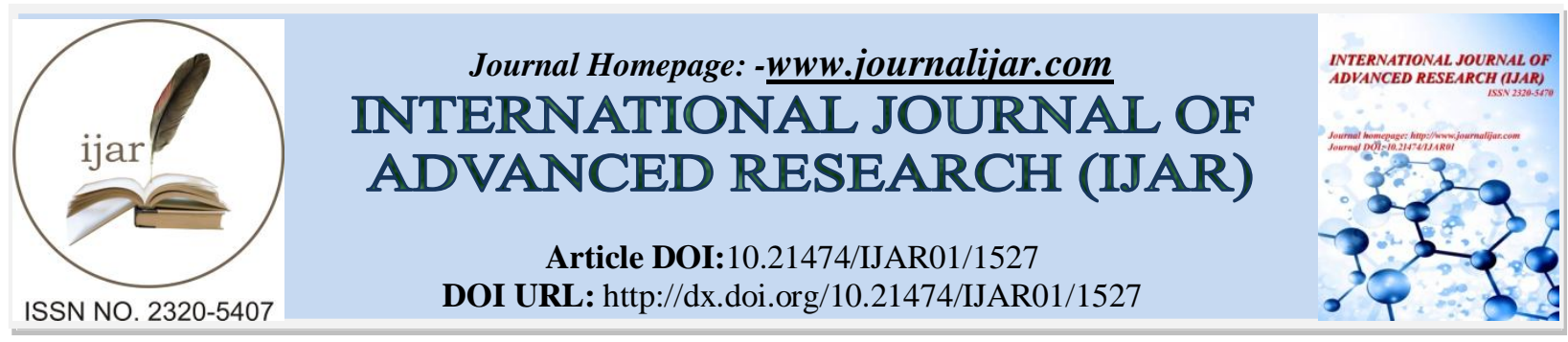

RESEARCH ARTICLE

\title{
EVALUATION OFSELECTED FRUIT PEELS AS NATURAL ANTIOXIDANT SOURCE AND TO VERIFY THE EFFICACY IN INCREASING THE SHELF LIFE OF COMMERCIAL PANEER.
}

*Aalolam K. P., Nayanathara A. R. And Reshma John.

PG Department of Environmental Sciences, All Saints' College, Thiruvananthapuram.

\section{Manuscript Info}

Manuscript History

Received: 16 July 2016

Final Accepted: 19 August 2016

Published: September 2016

Key words:-

Antioxidant activity, Ethanol, Fruit peels,Paneer, Peroxide.

\section{Abstract}

Fruit peels are valuable source of bioactive compounds. This work reports a study on the evaluation of total phenol, flavonoid, anthocyanin content and antioxidant activity of selected fruit peels. The objective of this investigation is to compare the efficiency of the antioxidant activity of selected fruit peels in reducing the peroxide effect of commercial paneer and thereby increasing its shelf life.The extraction was carried out using ethanol as solvent. The highest antioxidant activity was observed in Punica granatum followed by Citrus sinensis and Citrullus lanatus. Theseextracts (1-3\%) when added to paneer (in consecutive 0-8 days) showed a considerable reduction in the peroxide value enhancing its shelf life. In the results accomplished, the reduction in peroxide activity was shown was in the following order, Punica granatum >Citrus sinensis > Citrullus lanatus. The statistical analysis showed a strong positive correlation between phenolic and antioxidant activity.

Copy Right, IJAR, 2016,. All rights reserved.

\section{Introduction:-}

An antioxidant is any substance which when present at low concentrations compared with that of an oxidisable substrate significantly delays or inhibits oxidation of that substrate (Halliwell andGutteridge., 1995). The growing interest in natural antioxidants has restricted the use of synthetic antioxidant owing to its toxicity, carcinogenicity in human body (Nantitanon et al., 2010). Hence the commonly used synthetic antioxidants like butylated hydroxytoluene (BHT), propyl gallate (PG) are presumed unsafe to be used for food and medical purpose. Recent research works reveal that, the fruit peels can be reused as an important source of natural antioxidant meanwhile minimizing the environmental impact. The majority of fruit peels exhibited 2 to 27 fold higher antioxidant activity than the fruit pulp (Guo et al., 2003).

Paneer is an acid coagulated dairy product, which is similar to the western cottage cheese and Tofu (Soy paneer). It is an important Indian traditional coagulated dairy product. 1\% of the country's total milk production is converted into paneer butthe major hurdle in its commercial production is its relatively shorter shelf life of paneer. The shelf life period and stability of various food products, especially those containing fat can be improved by the addition of antioxidants. This emphasizes the importance of using antioxidants in controlling lipid oxidation in dairy products.

The present study was undertaken with the following objectives- a)To compare phenolic, flavonoid, anthocyanin and antioxidant activity of selected fruit peels b) To evaluate the effect of selected antioxidant extract in enhancing

Corresponding Author:-Aalolam K. P.

Address:-PG Department of Environmental Sciences, All Saints' College. Thiruvananthapuram. 
the shelf life of paneer c) To find out a cheap, easily available, eco-friendly alternative for synthetic antioxidants and d) To find out a better option to manage the wastes in industrial processing of fruits

\section{Material and methods:-}

Selected Samples:-

Punica granatum, Citrus sinensis, Citrullus lanatus, Paneer

\section{Chemicals Employed:-}

10\% Aluminium chloride, Catechin, Chloroform, Distilled water, Diphenyl picryl hydrazyl, Ethanol, FolinCiocalteu Reagent, Gallic acid, Glacial acetic acid, Potassium chloride, 0.025M Potassium iodide, 0.025M Sodium acetate, $20 \%$ Sodium carbonate, 1M Sodium hydroxide, 5\% Sodium nitrite, $0.01 \mathrm{~N}$ Sodium thiosulphate solution ,Starch solution.

\section{Preparation of fruit peel:-}

The fruits with no apparent physical damage were procured from a local market, Trivandrum, Kerala. The peels were manually separated from the pulp and washed to remove adhered impurities on the surface. It is followed by separation the peels from pulp manually. The peels were thensun dried for a week and ground to fine powder.The dried powders of selected fruit peel were extracted by cold percolation method (Parekh et al., 2007). $10 \mathrm{~g}$ of the dried peel powder is added to a $100 \mathrm{ml}$ of ethanol taken in a conical flask. The extraction mixture is then kept in an orbital shaker at $120 \mathrm{rpm}$ for 24 hours. The peel residues were then removed using Whatman filter paper and extract is then concentrated by air drying for 5 days. Dried extract was stored at $4^{0} \mathrm{C}$ till use.

Table 1:-Methodology adopted.

\begin{tabular}{|c|c|c|}
\hline Parameters & Methods employed & Mathematical Calculation \\
\hline $\begin{array}{l}\text { Total Phenol } \\
\text { Content } \\
\text { (TPC) }\end{array}$ & $\begin{array}{l}\text { Total phenolic compounds were } \\
\text { quantified by Folin-Ciocalteu method } \\
\text { (Singleton et al., 1999). Total phenol } \\
\text { values are expressed in terms of gallic } \\
\text { acid equivalent. }\end{array}$ & 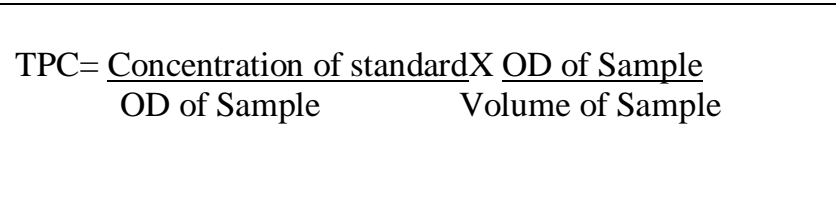 \\
\hline $\begin{array}{l}\text { Total Flavonoid } \\
\text { Content (TFC) }\end{array}$ & $\begin{array}{l}\text { Total flavonoid content was estimated } \\
\text { by colorimetric method described by } \\
\text { (Zhishen et al., 1999). The flavonoid } \\
\text { content was expressed as milligrams of } \\
\text { catechin equivalents. }\end{array}$ & $\mathrm{TFC}=\frac{\text { Concentration of standardX }}{\text { OD of Sample } \quad \text { Volume of Sample }}$ \\
\hline $\begin{array}{c}\text { Total } \\
\text { Anthocyanin } \\
\text { Content (TAC) }\end{array}$ & $\begin{array}{l}\text { Anthocyanin content of the apple peels } \\
\text { was measured using a } \\
\text { spectrophotometric pH differential } \\
\text { protocol (Boyles } \text { et al., 1993; Liu et al., } \\
\text { 2002). Anthocyanin content was } \\
\text { expressed as milligrams of cyanidin 3- } \\
\text { glucoside equivalents }\end{array}$ & $\begin{array}{l}\text { Total anthocyanins }=\mathrm{A} \times \mathrm{MW} \times 1000 /(\mathrm{E} \times \mathrm{C}) \\
\text { Where, } \mathrm{A}(\text { absorbance })=(\mathrm{A} 515-\mathrm{A} 700) \mathrm{pH} 1.0-(\mathrm{A} 515- \\
\mathrm{A} 700) \mathrm{pH} 4.5, \mathrm{MW} \text { is molecular weight for cyanidin 3- } \\
\text { glucoside })=449.2, \mathrm{E} \text { is the molar absorptivity of cyanidin } \\
3 \text {-glucoside }=26900 \text { and } \mathrm{C} \text { is the concentration of the } \\
\text { buffer in milligrams per milliliter. }\end{array}$ \\
\hline $\begin{array}{c}\text { Total } \\
\text { Antioxidant } \\
\text { Activity (TAA) }\end{array}$ & $\begin{array}{l}\text { The scavenging activity on DPPH } \\
\text { radical of different extracts was } \\
\text { determined by the method reported by } \\
\text { (Okonogi et al., 2007). }\end{array}$ & $\begin{array}{l}\text { Radicalscavengingactivity } \%=1-\left(\mathrm{A}_{1}-\mathrm{A}_{2}\right) / \mathrm{A}_{0} \times 100 \\
\text { Where } \mathrm{A}_{0} \text { is the absorbance of a control, } \mathrm{A}_{1} \text { is the } \\
\text { absorbance of DPPH solution in the presence of a sample; } \\
\mathrm{A}_{2} \text { is the absorbance without DPPH solution. }\end{array}$ \\
\hline $\begin{array}{c}\text { Peroxide Value } \\
\text { determination }\end{array}$ & $\begin{array}{l}\text { Control was prepared without } \\
\text { antioxidant extract addition. The other } \\
\text { variations include addition of } \\
\text { antioxidant extract (fruit peels)in liquid } \\
\text { form at different levels of }(1 \%,-3 \%) \\
\text { to } 3 \mathrm{~g} \text { of Paneer. }\end{array}$ & $\begin{array}{l}\text { Peroxide value }=((\mathrm{S}-\mathrm{B}) \times \mathrm{N} \times 100) / \mathrm{W}((\text { Adam } \text { et al }, 2006) \\
\text { Where, } \mathrm{S}, \mathrm{B}, \mathrm{N} \text { and } \mathrm{W} \text { are the volume of titrant of sample, } \\
\text { blank, normality of sodium thiosulphate and weight of } \\
\text { sample respectively. }\end{array}$ \\
\hline
\end{tabular}




\section{Results and Discussion:-}

Comparison of phenol, flavonoid, anthocyanin and antioxidant activity:-

Among those examined, the maximum total phenolic content (TPC) of $449.600 \mathrm{mg} / \mathrm{g}$ was found in Punica granatum. This result is comparable to the work done by Shiban et al, (2012) whereas the least quantity of 130.339 $\mathrm{mg} / \mathrm{g}$ was obtained in Citranullus lanatus that shadows the work published by Ghasemi et al (2009). Citrus sinensis showed a total phenol content of $169.580 \mathrm{mg} / \mathrm{g}$. The total phenolic constituent in Punica granatum can be attributed due to the presence of ellagic tannins and ellagic acid in the fruit peels

The maximum flavonoid content (TFC) of $60.01 \mathrm{mg} / \mathrm{g}$ was found in Punica granatum, a similar work was reported by Elfalleh et al., 2012, whereas a minimum of $10 \mathrm{mg} / \mathrm{g}$ was obtained in Citranullus lanatuswhich is in accordance with (Okafor et al., 2015).Citrus sinensisshowed $23.20 \mathrm{mg} / \mathrm{g}$ of flavonoid content, which is in agreement with Ghasemi et al., 2009. The flavonoids found in Punica granatum may be due to the flavonols quercetin, myricetin, kaempferol, isorhamnetin and their glycosides (Kanner et al., 1994).

Punica granatum showedmaximum anthocyanin content (TAC) of $102.41 \mathrm{mg}$ that agrees with the result of Elfalleh et al (2013) and a minimum of $17.88 \mathrm{mg}$ was found in Citrulluslanatus. Recent researches reveal that delphinidin, cyanidin, and pelargonidin, found in Punica granatumcould be responsible for the anthocyanin content.

Table2:-Comparison of phenol, flavonoid, anthocyanin and antioxidant activity.

\begin{tabular}{|c|c|c|c|}
\hline Selected Fruit Sample & $\begin{array}{c}\text { Total Phenol Content } \\
\text { (TPC) }\end{array}$ & $\begin{array}{c}\text { Total Flavonoid content } \\
\text { (TFC) }\end{array}$ & $\begin{array}{c}\text { Total Anthocyanin content } \\
\text { (TAC) }\end{array}$ \\
\hline Punica granatum & 309.340 & 60.01 & 102.41 \\
\hline Citrus sinensis & 169.580 & 23.20 & 080.50 \\
\hline Citrullus lanatus & 130.339 & 10.00 & 017.88 \\
\hline
\end{tabular}

Figure 1:-Comparison of phenol, flavonoid, anthocyanin and antioxidant activity.

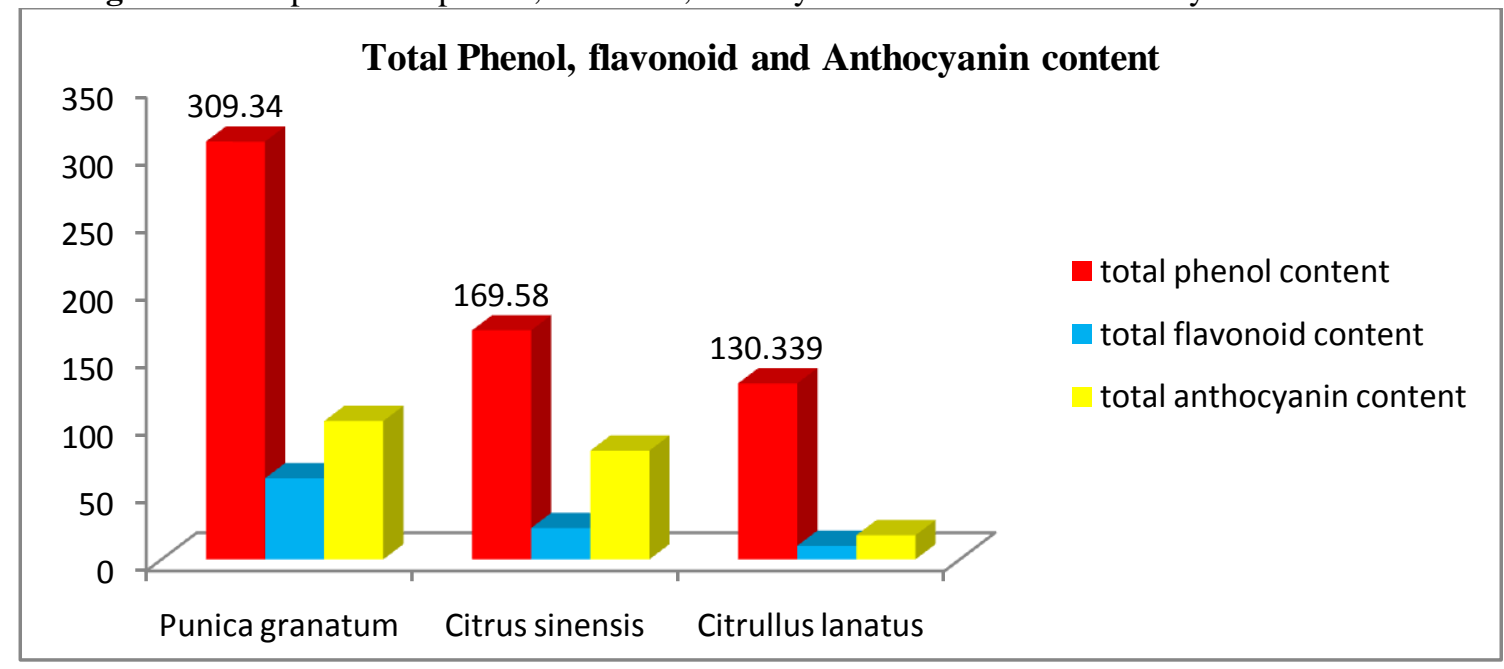

Comparison of Antioxidant Activity of Selected fruit peels:-

The maximum antioxidant activity of $86 \%$ was shown by Punica granatum, which is similar to the result obtained by Singh and Emmanuel., 2012 and the minimum antioxidant activity of 16\% was shown by Citranullus lanatus. Antioxidant properties depend on the polyphenol components, primarily phenolic acid, and flavonoids. The antioxidant activity increases with the extraction time because an increase in extraction time increases the amount of bioactive compounds extracted from the fruit peels

Table3:-Comparison of Antioxidant Activity of Selected fruit peels.

\begin{tabular}{|c|c|c|}
\hline Serial number & Name of sample & Total Antioxidant Activity \% \\
\hline 01 & Punica granatum & 92 \\
\hline 02 & Citrus sinensis & 46 \\
\hline 03 & Citrullus lanatus & 16 \\
\hline
\end{tabular}


Figure 2:- Comparison of antioxidant activity of selected fruit peels.

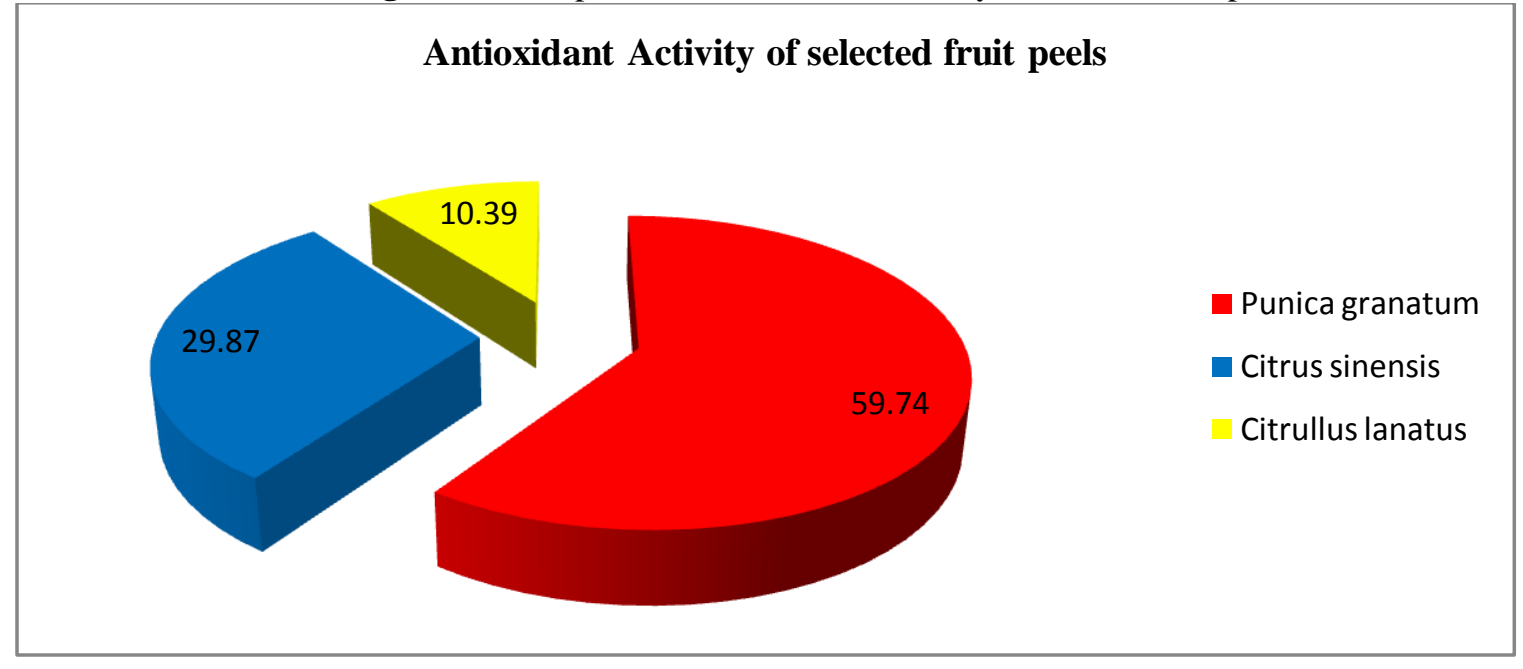

Comparison of 1-2\% antioxidant activity in reduction of peroxide activity of paneer:-

The peroxide value of each paneer sample with $1 \%$ fruit peel extract showed an increase with the storage period. The maximum ability to reduce peroxide effect of paneer after 8 days was shown by Punica granatum, the peroxide value was only 1.35 whereas control showed a peroxide value of 2.6. The antioxidant extract from Citrullus lanatus showed the lowest reduction in peroxide value. Citrus sinensis extract reduced the peroxide value of paneer from 2.6 to 2.32 after 8 days.

To the paneer sample $2 \%$ of the selected antioxidant extracts were added and the peroxide value reduction in paneer was periodically checked $\left(0,2,4,6,8\right.$ days). On the $8^{\text {th }}$ day the maximum ability to reduce peroxide effect in paneer was shown by Punica granatum, the peroxide value was only 1.31 whereas control showed a peroxide value of 2.56 . whereas the antioxidant extract from Citrullus lanatus showed the lowest reduction in peroxide value.Citrus sinensis extract reduced the peroxide value of paneer from 2.56 to 2.16

The antioxidant activity increases with increase in extraction time because an increase in extraction time increases the amount of bioactive compounds extracted from the fruit peels. The reducing property of polyphenols makes them potent free radical scavengers. This property helps in the reduction of peroxide (Shahidi., Wanasunadra., 1992).

Table 4:-effect of 1-2 \% antioxidant extract in paneer.

\begin{tabular}{|c|c|c|c|c|c|c|c|c|c|c|}
\hline \multirow{2}{*}{ Fruit peel Sample } & \multicolumn{9}{|c|}{$1 \%$ antioxidant extract addition to paneer } & \multicolumn{5}{c|}{$\begin{array}{c}\text { 2\% antioxidant extract addition to } \\
\text { addition of paneer }\end{array}$} \\
\cline { 2 - 13 } & $\begin{array}{c}0^{\text {th }} \\
\text { day }\end{array}$ & $\begin{array}{c}2^{\text {nd }} \\
\text { day }\end{array}$ & $\begin{array}{c}4^{\text {rd }} \\
\text { day }\end{array}$ & $\begin{array}{c}6^{\text {th }} \\
\text { day }\end{array}$ & $\begin{array}{c}8^{\text {th }} \\
\text { day }\end{array}$ & $\begin{array}{c}0^{\text {th }} \\
\text { day }\end{array}$ & $\begin{array}{c}2^{\text {nd }} \\
\text { day }\end{array}$ & $\begin{array}{c}4^{\text {th }} \\
\text { day }\end{array}$ & $\begin{array}{c}6^{\text {th }} \\
\text { day }\end{array}$ & $\begin{array}{c}8^{\text {th }} \\
\text { day }\end{array}$ \\
\hline Control & 0.09 & 0.09 & 0.09 & 0.09 & 0.09 & 0.09 & 0.09 & 0.09 & 0.09 & 0.09 \\
\hline Punica granatum & 0.09 & 0.3 & 0.5 & 0.52 & 1.35 & 0.09 & 0.23 & 0.4 & 0.6 & 1.31 \\
\hline Citrus sinensis & 0.09 & 0.6 & 1.56 & 2.3 & 2.32 & 0.09 & 0.4 & 1.2 & 1.4 & 2.16 \\
\hline Citrullus lanatus & 0.09 & 1,2 & 1.6 & 2.35 & 2.36 & 0.09 & 1.1 & 1.55 & 2.32 & 2.35 \\
\hline
\end{tabular}


Figure 3:-effect of 1-2 \% antioxidant extract in paneer.

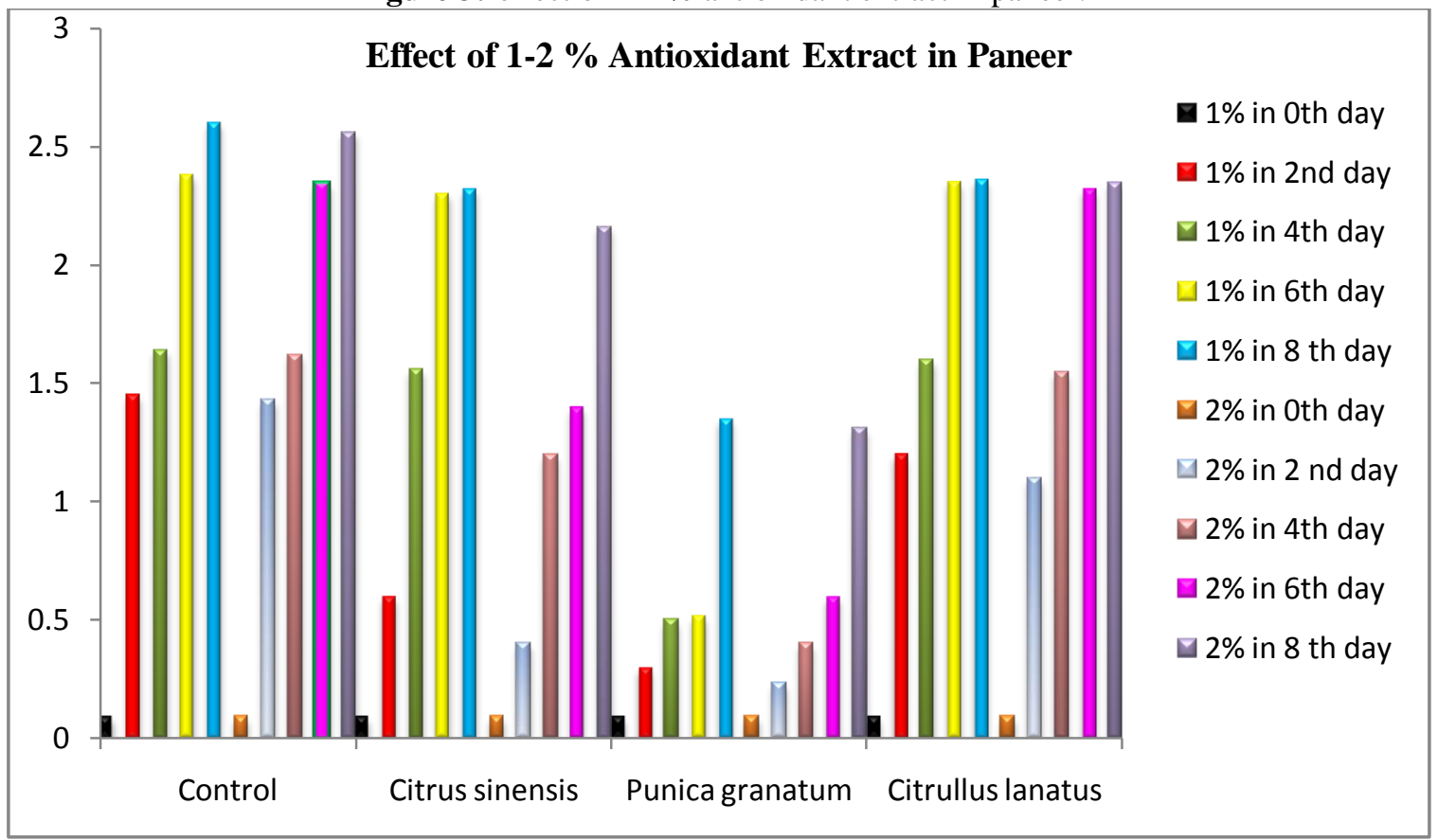

Statistical analysis:-

There was a high positive correlation between Total Phenolic content (TPC) and Total Antioxidant Activity (TAC), $\mathrm{r}=0.883$

\section{Conclusion:-}

The study demonstrates the comparison of polyphenol compounds and the antioxidant properties of certain fruit peel as antioxidant status to fight against free radical damage. It can be concluded that the selected fruit peels can be successfully employed in reducing the peroxide formation in food paneer. Hence this selected peel extracts, owing to their antioxidant properties can be a better substitute for widely used synthetic antioxidants for extending shelf life of paneer.

To achieve this goal, future development efforts should address below objectives a) Optimize and scale up the extraction procedures of bioactive constituents. b) Identify the optimal extraction procedure on the composition and activity of obtained extracts without accepting the sensorial acceptability. c) Evaluate the economic feasibility of the alternative process of production of bioactive extracts.

\section{References:-}

1. Adams L. S ., Seeram N. P., Agarwal B. B., Takada Y., Sand D. et al. (2006): Pomegranate juice, total pomegranate ellagitannins, and punicalagin suppress inflammatory cell signaling in colon cancer cells. J Agric Food Chem., 54: 980-985.

2. Boyles, M. J., Wrolstad, R. E. (1993): Anthocyanin composition of red rasp berry juice: influences of cultivar, processing, and environmental factors. J of Food Sci, 1135-1141.

3. Ghasemi, K., Ghasemi, Y., Ebrahimzadeh, M. (2009): Antioxidant activity, phenol and flavonoid contents of 13 citrus species peels and tissues. Pakistan Journal in Pharmaceutical Science, 277-281.

4. Guo C., Li Y., Yang J., Wei J., Xuand J. and Cheng S. (2006): Evaluation of antioxidant properties of pomegranate peel extract in comparison with pomegranate pulp extract. J of Food and Chem., 96: 254-260.

5. Halliwell B. and Gutteridge J. M. C. (1995): The Definition and Measurement of Antioxidants in Biological Systems. Free Radical Bio and Med., 18(1): 125-126

6. Kanner, J., Frankel, E., Granit, R., German, B. \& Kinsella, E. (1994): Natural antioxidants in grapes and wines. $\mathrm{J}$ of Agri and food Chem., 64-69. 
7. Liu, M., Li, X. Q., Weber, C., Lee, C. Y., Brown, J. B. \& Liu, R. H. (2002): Antioxidant and antiproliferative activities of raspberry.J of agri and Food Chem., 2926-2930.

8. Nantitanon W., Yotsawimonwat, S. and Okonogi S. (2010): Factors influencing antioxidant activities and total phenolic content of guava leaf extract. Food Sci and Technol., 43(7): 1095-1103

9. Okonogi, S., C. Duangrat., S. Anuchpreeda., S. Tachakittirungrod., S. Chowwanapoonpohn. (2007): Comparison of antioxidant capacities and cytotoxicities of certain fruit peels. J of Food Chem., 839-846.

10. Parekh J, Chanda S. (2007): In vitro anti-bacterial activity of crude methanol extract of WoodfordiafructicosaKurz flower (Lythraceae). BrazJofmicrobio., 38: 204-207.

11. Shahidi F. and Wanasunadra P. K. J. (1992): Phenolic antioxidants. Crit. Rev. Food Sci. Nutr.,32:67-103.

12. Shiban S.., Mutahar., Mutlag, Al, Otaibi M.., Najeeb, S. Al. Zoresky. (2012): Antioxidant activity of pomegranate (Punica granatum) fruit peels. Food and Nutr Sci., 991-996.

13. Singh S., Immanuel G. (2014): Extraction of antioxidants from fruit peels and its utilization in paneer. J food process Technol., 5: 2157-7710.

14. Walid, Elfalleh., Hedia, Hannachi., Nizar, Tlili., Yassine, Yahia., Nizar, Nasri, \& Ali, Ferchichi. (2012): Total phenolic contents and antioxidant activities of pomegranate peel, seed, leaf and flower. Journal of Medicinal Plants Res., 4724-4730.

15. Zhishen, J., Mengcheng, T., Jianming, W. (1999): The determination of flavonoid contents in mulberry and their scavenging effects on superoxide radicals. Food Chem., 555-559. 